研究論文《

\title{
$\mathrm{Li}(\mathrm{NCM}) \mathrm{O}_{2}$ 係 二次電池 工程스크랩의 炭素還元處理에 의한 리튬回收 및 NCM 粉末의 浸出擧動
}

\author{
中金大原・張成太 \\ (주)타운마이닝캄파니

\section{Recovery of Lithium and Leaching Behavior of NCM Powder by Carbon Reductive Treatment from $\mathrm{Li}(\mathrm{NCM}) \mathrm{O}_{2}$ System Secondary Battery Scraps} \\ *Dae Weon Kim and Seong Tae Jang \\ Townmining Company Ltd., 260 Gongdandong, Kumi, Gyeongsangbukdo, 730-340, Korea \\ 요 약 \\ $\mathrm{Li}(\mathrm{NCM}) \mathrm{O}_{2}$ 계 폐리튬전지 공정 스크랩의 재활용 연구의 일환으로서 리튬화합물의 회수와 $\mathrm{NCM}$ 전구체를 제조하기 위한 침출거 \\ 동에 대하여 살펴보았다. 우선 탄소를 이용하여 층상 구조의 $\mathrm{NCM}$ 계 산화물 분말을 분해시켰으며, $600^{\circ} \mathrm{C}$ 이상의 탄소반응으로 리 \\ 튬은 탄산리튬으로 변화시켰다. 탄산리튬은 수세 후 농축과정을 거쳐 순도 $99 \%$ 이상의 탄산리튬 분말로 회수하였다. 그리고 탄소 \\ 에 의한 환원 반응율은 $800^{\circ} \mathrm{C}$ 에서 약 $88 \%$ 을 나타내었으며, 탄소환원 처리 후 분말에 대한 황산 침출 결과, $2 \mathrm{M}$ 이상의 황산농도 \\ 에서 코발트, 니켈, 망간의 침출율은 $99 \%$ 이상이었다.
}

주제어 : 자원재활용, $\mathrm{NCM}$ 계 리튬이온전지, 탄소환원, 침출

\begin{abstract}
A study on the recovery of lithium and leaching behavior of NCM powder by carbon reduction for NCM-system Li-ion battery scraps was conducted. First of all, the oxide powders of NCM-system with layer structure were decomposed by carbon, lithium was converted to lithium carbonate by carbon reaction at above $600^{\circ} \mathrm{C}$. The lithium carbonate powders with $99 \%$ purity were manufactured by washing method with water and concentration process for NCM powder after carbon reduction. The reaction yield was approximately $88 \%$ at $800^{\circ} \mathrm{C}$ by carbon reduction. At this time, leaching efficiency at $2 \mathrm{M}$ sulfuric acid concentration was over $99 \%$ for cobalt, nickel and manganese.
\end{abstract}

Key words : scrap recycling, NCM-system lithium ion battery, carbon reduction, leaching

1. 서 론

폐전지는 우리가 일상적으로 사용하고 있는 핸드폰,
노트북 등 각종 전자기기의 전원으로 사용된 일차전지 및 이차전지가 그 수명을 다하여 폐기되는 폐기물을 말 한다. 특히, 최근에는 전자산업의 비약적인 발전과 전자

\footnotetext{
* Received : March 25, $2013 \cdot$ Revised : May 16, $2013 \cdot$ Accepted : June 4, 2013

₹Corresponding Author : Dae Weon Kim (E-mail : mdsimul@naver.com)

Research Center, Townmining Company Ltd., 260 Gongdandong, Kumi, Gyeongsangbukdo, 730-340, Korea

Tel : +82-54-462-6117 / Fax : +82-54-462-6122

(c) The Korean Institute of Resources Recycling. All rights reserved. This is an open-access article distributed under the terms of the Creative Commons Attribution Non-Commercial License (http://creativecommons.org/licenses/by-nc/3.0/), which permits unrestricted non-commercial use, distribution and reproduction in any medium, provided the original work is properly cited.
} 
제품의 라이프 싸이클이 짧아짐에 따라 전자기기 등과 같은 폐기물의 발생량이 급증하고 있으며, 이에 폐전지 의 양도 늘어나고 있는 추세이다. 그러나 이에 따른 적 절한 처리 기술의 미비로 인하여 환경문제가 심각하게 대두되고 있다. 한편 이러한 폐기물에는 고가의 귀금속 외에 구리, 코발트, 니켈, 망간, 알루미늄, 리튬 등의 유 가금속이 함유되어 있어 도시광산으로서 매력적인 자원 으로 급부상하고 있다.

특히, 리튬이차전지 ${ }^{1-4)}$ 는 전자 산업의 발전으로 인해 휴대전화, 노트북 등과 같은 이동성이 매우 간편한 IT 관련 제품과 같은 정보통신기기 및 전자기기의 운용에 필요한 고성능 에너지를 효과적으로 사용하기 위하여 많이 이용되고 있다. 소형 가전기기 및 모바일용은 $\mathrm{LiCoO}_{2}(\mathrm{LCO})$ 계 양극물질이 주로 사용되어 왔으나, 이 는 코발트의 높은 가격과 폭발의 위험성으로 고출력을 요구하는 중/대형 전지에는 사용이 부적합하기 때문에 이 에 고가의 코발트를 다량 사용하는 $\mathrm{LCO}$ 를 대체할 수 있는 양극소재로 각광을 받는 것이 3 원계 양극물질로서 니켈, 코발트, 망간의 3 가지 금속이 주를 이루고 있다.

현재 하이브리드 전기자동차(HEV)용 고용량 양극소 재로 $\mathrm{Li}\left(\mathrm{Ni}_{\mathrm{x}} \mathrm{Co}_{\mathrm{y}} \mathrm{Mn}_{\mathrm{z}}\right) \mathrm{O}_{2}(\mathrm{NCM})$ 이 적용되어지고 있다. 이에 본격적으로 생산될 것으로 예측되는 전지자동차용 $\mathrm{NCM}$ 계 양극소재에 있어서 불량 스크랩에 대한 재처리 및 재활용의 필요성이 대두되고 있다.

폐리튬이온전지의 양극 스크랩으로부터 유가금속을 회수하는 방법에 대한 연구는 다수 수행되었다.5-13) 1998년 일본의 Zhang 등5)은 폐리튬이온전지로부터 코 발트와 리튬을 회수하기 위하여 염산침출과 용매추출법 을 이용하여, 리튬 및 코발트의 회수율에 대한 침출제 의 농도, 온도, 침출시간, 고/액 비율 등의 영향을 살펴 보았으며, 코발트는 용매추출로 황산코발트 결정형태로 회수하고 리튬은 탄산나트륨을 사용하여 탄산리튬으로 회수하는 연구를 수행하였다.

2001년 이탈리아의 Contestable 등6)은 폐리튬이온전 지로부터 코발트를 회수하여 다시 전극재료로 사용하기 위한 실험을 하였다. 전지 해체 후에 N-methyl pyrrolidone (NMP)을 이용하여 알루미늄과 구리 포일로부터 $\mathrm{LiCoO}_{2}$ 를 분리하였으며, 분리된 $\mathrm{LiCoO}_{2}$ 를 염산 침출하 여 침출용액으로부터 $\mathrm{NaOH}$ 를 이용하여 수산화코발트 로 침전시켜 열처리한 산화코발트를 전극재료로 이용하 고 $\mathrm{Li}_{2} \mathrm{CO}_{3}$ 등 다른 금속들과 혼합한 후 전기화학적 성 질을 알아보았다.

또한 2001년에 $\mathrm{Lee}$ 와 $\mathrm{Kim}^{7}$ )은 황산용액에서 $\mathrm{LiCoO}_{2}$ 의
환원침출 거동에 대하여 자세하게 연구하였으며, 황산 농도, 침출온도, 초기광액농도, 과산화수소 첨가량, 반응 온도에 대한 조건을 확립하였다.

2002년 프랑스의 Castillo 등8)은 폐리튬이차전지로부 터 묽은 산을 이용한 침출효과와 수산화물 형태로의 선 택적 침전에 대한 연구를 수행하였다.

2005년 중국의 Nan 등9)은 폐리튬이차전지 활물질을 알칼리로 처리한 후 황산에 침출하여 코발트를 oxalate 형태로 침전시키고 Acorga-5640 및 Cyanex272를 사용 하여 구리 및 코발트를 용매추출로 회수하는 연구를 수 행하였다.

2009년 타이완의 Wang 등 ${ }^{10)}$ 은 NCM계 양극물질에 서 $4 \mathrm{M}$ 염산, 고액비 $20 \mathrm{~g} / \mathrm{L}$, 침출온도 $80^{\circ} \mathrm{C}$, 침출시간 $60 \mathrm{~min}$ 의 조건에서 실험하였으며, 망간은 $\mathrm{KMnO}_{4}$ 를 이 용하여 산화망간 및 수산화망간으로 회수하였고, 니켈 은 dimenthyglyoxime을 이용하여 추출하였으며, 코발트 는 $\mathrm{pH}=11$ 에서 $\mathrm{NaOH}$ 를 이용하여 수산화코발트를 회 수하고, 리튬은 $\mathrm{Na}_{2} \mathrm{CO}_{3}$ 를 이용하여 $\mathrm{Li}_{2} \mathrm{CO}_{3}$ 형태로 회 수하는 연구를 수행하였다.

2011년 중국의 Liang 등1)은 NCM계 폐리튬이온전 지에서 철은 sodium jarosite법을 이용하여 제거하였고, 구리는 N902를 이용하여 추출하였으며, 알루미늄의 수 산화알루미늄 형태로 침전시켰다. 침출조건은 $2.5 \mathrm{M}$ 황 산, 과산화수소수 $2.0 \mathrm{ml} / \mathrm{g}$, 고액비 $1 / 10$, 침출온도 $85^{\circ} \mathrm{C}$, 침출시간 $120 \mathrm{~min}$ 에서 니켈, 코발트, 망간은 $97 \%, 98 \%, 96 \%$ 로 침출효율을 얻었다고 보고하였다.

또한, 2011년 $\mathrm{Kim}$ 등 ${ }^{12)}$ 이 전기자동차용 폐리튬이온 전지 배터리팩을 물리적/화학적 처리를 통하여 니켈, 코 발트, 망간 양극물질 Precusor를 제조하였으며, 공침여 액을 이용하여 탄산리튬을 제조하는 연구를 수행하였다.

그러나 기존의 이차전지 양극물질을 재활용 방법은 먼저 유가금속인 코발트, 니켈, 망간을 회수하고, 리튬 은 탄산나트륨을 사용하여 탄산리튬 형태로 회수하게 되는데, 이 경우 나트륨이 불순물로 작용하여 여러 번 수세 공정을 거쳐야 하는 단점이 발생한다.

그래서 본 저자들 ${ }^{13)}$ 은 $\mathrm{NCM}$ 계 양극스크랩으로부터 수소환원 처리에 의해 리튬을 먼저 회수하고 $\mathrm{NCM}$ 분 말에 대하여 황산침출에 대한 연구를 발표하였다.

이에 본 연구에서는 기존 수소환원 처리 효과와 비교 하고 탄소에 의한 환원 처리 효과를 살펴보고자 $\mathrm{NCM}$ 계 양극스크랩 분말에 대하여 리튬을 약품 처리 없이 먼저 회수하고 나머지 니켈, 코발트, 망간 함유 분말에 대하여 황산 침출거동에 대하여 연구하였다. 


\section{2. 실험방법}

\section{1. 실험원료}

실험에 사용한 시료는 이전 발표 ${ }^{13)}$ 에서 사용한 국내 리튬이온전지 제조공정에서 발생하는 $\mathrm{NCM}$ 계 양극스크 랩으로 알루미늄 호일에 도포된 원료를 사용하였으며, 분쇄 및 분급을 통하여 $\mathrm{NCM}$ 계 분말을 회수하였다. 그 화학조성은 왕수로 침출한 후 ICP (Inductively Coupled Plasma, GBC Integra XL)로 분석하였으며, 그 결과를 Table 1에 나타내었다. 사용한 시료의 니켈, 코발트 및 망간의 금속비는 니켈 $18.3 \%$, 코발트 $15.6 \%$, 망간 $66.1 \%$ 로 망간계의 $\mathrm{NCM}$ 양극물질에서 나온 공정스크 랩이라 추정되어진다.

또한, NCM계 양극스크랩 분말 및 탄소환원을 위하 여 사용한 카본의 입도는 $0.1 \mu \mathrm{m}$ 에서 $80.0 \mu \mathrm{m}$ 까지 분 석하였으며, $\mathrm{NCM}$ 계 양극스크랩 분말의 D50 값은 약 $7.9 \mu \mathrm{m}$ 이였으며, 카본의 D50 값은 약 $5.8 \mu \mathrm{m}$ 로 측정되

Table 1. Chemical composition of NCM system Li-ion battery scraps $(\%)$

\begin{tabular}{|c|c|c|c|c|c|}
\hline Element & $\mathrm{Ni}$ & $\mathrm{Co}$ & $\mathrm{Mn}$ & $\mathrm{Li}$ & $\mathrm{Al}$ \\
\hline Content & 9.6 & 8.2 & 34.7 & 5.4 & 1.3 \\
\hline
\end{tabular}

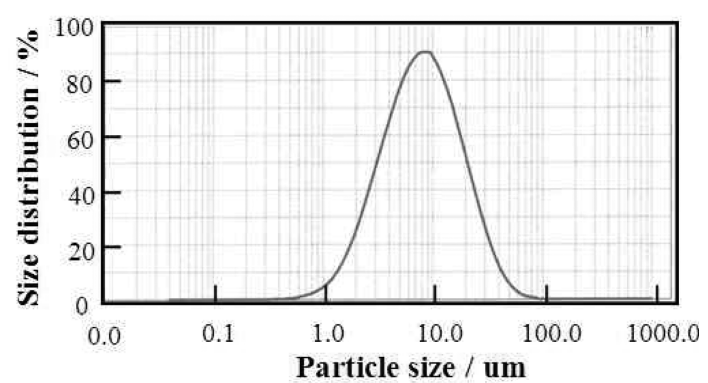

(a) NCM system scrap powder

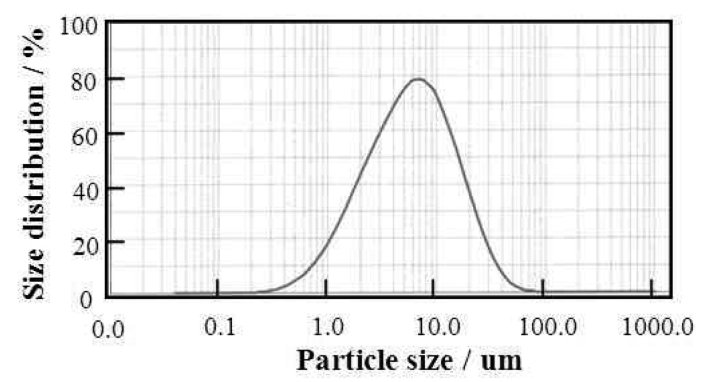

(b) carbon powder

Fig. 1. Size distribution; (a) NCM system Li-ion battery scrap powder, (b) carbon powder.
었다. 그에 대한 결과를 Fig. 1에 나타내었다.

그리고 $\mathrm{NCM}$ 계 양극스크랩 분말에 대한 XRD (XRay Diffraction, Rigaku) 결정상은 대표적인 $\mathrm{LiCoO}_{2}$ 층상구조를 하고 있었으며, 코발트 위치에 니켈과 망간 이 치환됨으로서 XRD 피크가 약간 오른쪽으로 이동되 어 있음을 알 수 있었다 ${ }^{14)}$. 이 시료에 대한 XRD 결 과를 Fig. 2에 나타내었다.

\section{2. 탄소환원실험}

실험에 사용한 $\mathrm{NCM}$ 계 양극스크랩 분말에서 먼저 리 틈을 회수하기 위하여 탄소환원을 실시하였다. 실험 장 치는 (주) $\mathrm{KF}$ 에서 제작한 로를 사용하였으며, 그 로의 개략도를 Fig. 3에 나타내었다.

실험 장치는 크게 가열부, 온도조절부, 가스조절부로 구성되었다. 가열부는 $\mathrm{SiC}$ 발열체를 사용하였으며, 사

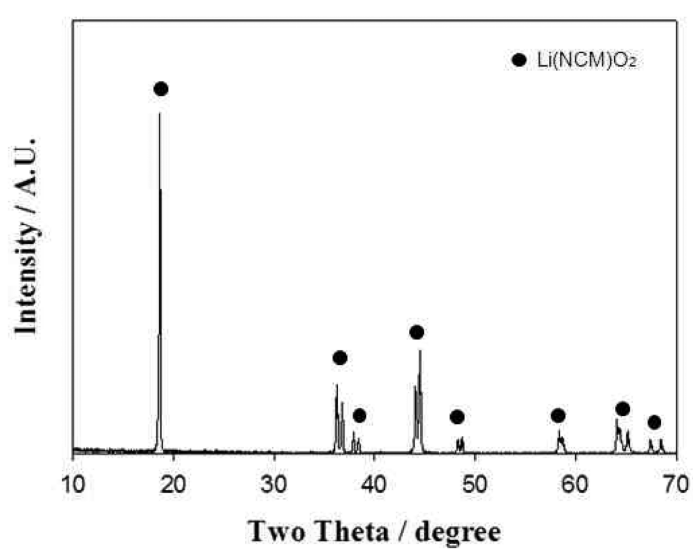

Fig. 2. XRD patterns of NCM system Li-ion battery scraps.

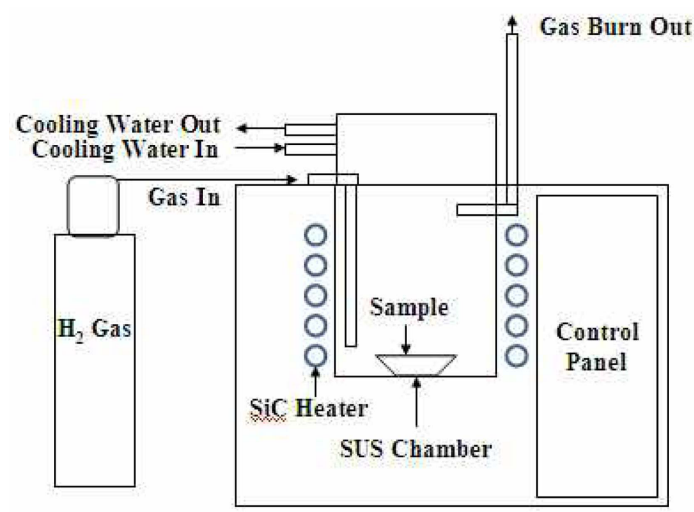

Fig. 3. A schematic diagram of the experimental apparatus for reduction of NCM system Li-ion battery scraps. 


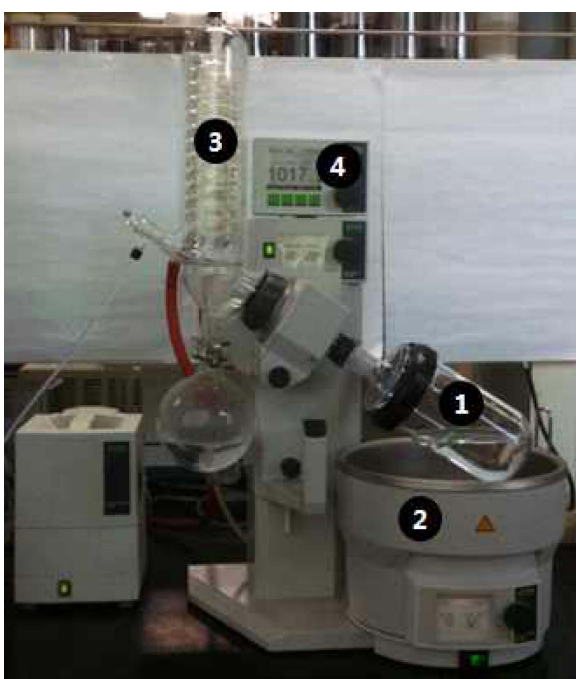

Fig. 4. The photograph of experiment apparatus. (1) glass reactor (2) bath (3) condensation tube (4) pressure gauge.

용온도는 약 $1300^{\circ} \mathrm{C}$ 로 환원 시에는 $\mathrm{SUS} 316$ 챔버를 이용하기 때문에 사용온도는 약 $900^{\circ} \mathrm{C}$ 이하가 적당하 다. 온도조절부는 R-type 열전대와 PID 온도제어장치를 이용하였다. 가스조절부는 3 가지 종류의 가스를 흘려보 낼 수 있도록 설계를 하였다.

탄소환원 실험은 질소가스 분위기에서 실시하였으며, 질소가스는 정량적으로 흘러들어 갈 수 있도록 $5 \mathrm{~L} / \mathrm{min}$ 용 flow meter를 사용하여 $1 \mathrm{~L} / \mathrm{min}$ 로 흘려보냈다. 또한, 탄소환원 반응이 잘 일어나도록 $\mathrm{NCM}$ 계 양극스크랩 분 말과 카본을 $1: 1.5$ 몰비로 측량하여 볼밀에 넣고 약 24 시간 동안 혼합하였다.

혼합된 분말은 챔버 $(200 \mathrm{~mm} \times 200 \mathrm{~mm} \times 400 \mathrm{~mm})$ 안에 사각 모양의 알루미나 도가니 $(100 \mathrm{~mm} \times 100 \mathrm{~mm} \times 50 \mathrm{~mm})$ 에 약 $100 \mathrm{~g}$ 의 샘플을 취하여 실험을 실시하였다.

\section{3. 리튬회수실험}

탄소환원 처리된 $\mathrm{NCM}$ 계 이차전지 공정 스크랩 분말 은 식 (1)의 반응식과 같이 탄산리튬 형태로 반응하기 때문에 별도의 약품처리 없이 수세만으로도 리튬을 회 수할 수 있다.

$$
2 \mathrm{Li}(\mathrm{M}) \mathrm{O}_{2}+2 \mathrm{C} \leftrightarrow \mathrm{Li}_{2} \mathrm{CO}_{3}+2 \mathrm{M}+\mathrm{CO}
$$

수세는 고액비를 $100 \mathrm{~g} / 4000 \mathrm{~mL}$ 으로 하였으며, 수세 시간은 3 시간 실시하여 여과 후 침출액을 $\mathrm{ICP}$ 로 분석
하였다. 그 후 리튬은 증발농축기를 사용하여 회수하였 으며, 사용된 증발농축기는 Fig. 4에 나타내었다. 증발 농축에 사용한 조건은 온도 $70^{\circ} \mathrm{C}$, 압력 $100 \mathrm{mbar}$ 로 실 험하였다.

\section{4. 산침출실험}

온도에 따라 탄소환원 처리된 NCM계 이차전지 공정 스크랩 분말에 대한 황산에 따른 유가금속의 침출거동 을 알아보기 위한 실험을 실시하였다.

$\mathrm{XRD}$ 분석에 의하여 탄소환원으로 반응이 진행되어 거의 완료가 이루어지는 온도를 $800^{\circ} \mathrm{C}$ 로 판단되어 $400^{\circ} \mathrm{C}$ 에서 $800^{\circ} \mathrm{C}$ 까지 $100^{\circ} \mathrm{C}$ 간격으로 1 시간 열처리하 였다. 그리고 리튬을 수세에 의해 회수한 후 수세한 분 말을 $2 \mathrm{M}$ 의 황산농도로 하여 침출하였으며, 이때 고액 비는 $100 \mathrm{~g} / \mathrm{L}$ 고정시켜 침출실험을 하였다.

\section{3. 결과 및 고찰}

\section{1. 탄소환원 실험}

우선 최적의 탄소환원 조건을 구하기 위하여 온도는 $400^{\circ} \mathrm{C}, 500^{\circ} \mathrm{C}, 600^{\circ} \mathrm{C}, 700^{\circ} \mathrm{C}, 800^{\circ} \mathrm{C}$ 가지 조건에서 각각 1 시간 실험하였다. $\mathrm{NCM}$ 계 양극스크랩 분말의 탄 소양에 따른 환원반응식은 다음과 같은 식 (1)으로 표 현할 수 있으며, 환원에 의한 반응율 식 (2)는 기상으 로 날아가는 일산화탄소의 양을 제외한 시료의 양을 투 입한 시료의 양으로 나누어서 구하였으며, 이때의 이론 적 무게 감소율은 $17.5 \%$ 였다.

환원에 의한 반응율 $(\%)=\frac{\text { 실제무게감량 }}{\text { 이론적무게감량 }} \times 100$

온도에 따른 탄소환원 반응율과 무게감량에 대한 결 과를 Fig. 5에 나타내었다. 탄소에 의한 환원반응에 따 른 무게 감소는 $400^{\circ} \mathrm{C}$ 에서도 일어나기 시작하였으며, 약 $3 \%$ 정도 감소하였다. $500^{\circ} \mathrm{C}$ 에서는 약 $7 \%, 600^{\circ} \mathrm{C}$ 에서는 약 $8 \%, 700^{\circ} \mathrm{C}$ 에서는 약 $13 \%, 800^{\circ} \mathrm{C}$ 에서는 약 $15 \%$ 로 감소하였다.

탄소환원의 경우에는 기존 연구인 ${ }^{13)}$ 수소환원 실험과 는 달리 환원 후에도 소결되지 않고 분말상태 그대로 존재하였다. 환원에 의한 반응율은 온도가 상승함에 따 라 증가하였으며 $700^{\circ} \mathrm{C}$ 이상이 되어서야 $50 \%$ 를 넘어 서 약 $75 \%$ 정도를 달성하였으며, $800^{\circ} \mathrm{C}$ 에서는 약 $88 \%$ 를 나타내었다. 


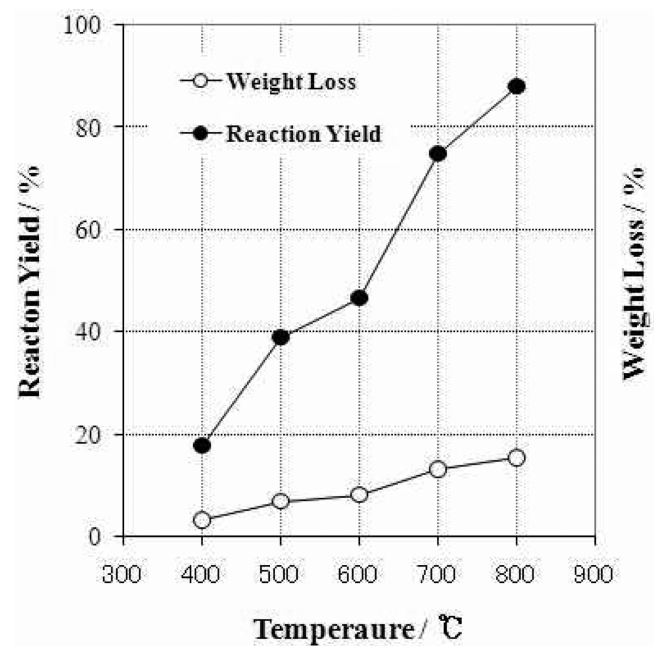

Fig. 5. The reaction rate and weight loss according to the temperature of NCM system Li-ion battery scrap powders.

그리고 탄소환원 분말과 리튬을 회수하기 위하여 탄 소환원 후 수세한 분말에 대하여 초기의 $\mathrm{Li}(\mathrm{NCM}) \mathrm{O}_{2}$ 의 결정구조가 환원온도에 따라 어떻게 변하는지 XRD 분 석을 실시하였으며, 그 결과를 Fig. 6 및 Fig. 7에 나 타내었다.

소정 온도에 따른 열처리 후의 결정구조의 결과를 보 면, $400^{\circ} \mathrm{C}, 1$ 시간 탄소환원 시에는 $\mathrm{Li}(\mathrm{NCM}) \mathrm{O}_{2}$ 결정구 조가 거의 변하지 않았으며, $500^{\circ} \mathrm{C}, 1$ 시간 탄소환원 시 에는 $\mathrm{Li}(\mathrm{NCM}) \mathrm{O}_{2}$ 결정구조가 약간 변하기 시작하였다. 그리고 $600^{\circ} \mathrm{C}, 700^{\circ} \mathrm{C}, 800^{\circ} \mathrm{C}$ 1시간 탄소환원 시에는 $\mathrm{Li}_{2} \mathrm{CO}_{3}, \mathrm{Co}, \mathrm{Ni}, \mathrm{MnO}$ 의 피크가 관측됨을 알 수 있었 다. 여기서 특이한 사항으로 망간의 경우에는 금속 상 태로 존재하지 않고 산화물 상태로 존재하였으며, 이는 생성된 $\mathrm{MnO}$ 가 $800^{\circ} \mathrm{C}$ 에서는 탄소로도 환원되지 않기 때문으로 판단된다. ${ }^{15)}$

그리고 탄소환원 후 수세한 분말의 경우에는 수세전 분말에 대한 결정상과 유사하게 보여지고 있으나, 가장 큰 차이점은 수세에 의해 $\mathrm{Li}_{2} \mathrm{CO}_{3}$ 성분이 용해되어 그 결정 피크가 없어짐을 알 수 있었다.

\section{2. 리튬회수실험}

탄소에 의한 환원반응이 완료된 분말 $100 \mathrm{~g}$ 을 증류수 $4000 \mathrm{~mL}$ 를 사용하여 3시간 동안 1회 수세하였으며, 그 에 대한 리튬 침출율은 Fig. 8에 나타내었다.

$400^{\circ} \mathrm{C}$ 로 탄소환원 처리된 분말의 경우, 리튬 침출율

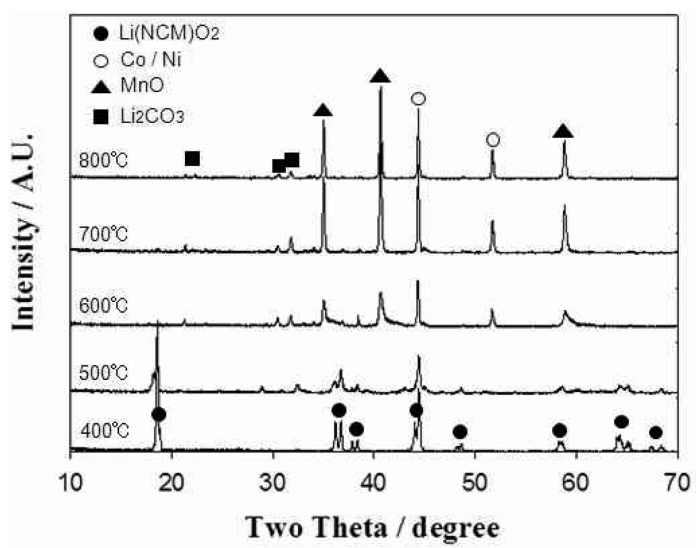

Fig. 6. XRD patterns of NCM system Li-ion battery scrap powders before washing process. $\left(\mathrm{Li}(\mathrm{NCM}) \mathrm{O}_{2}\right.$, $\left.\mathrm{Co} / \mathrm{Ni}, \boldsymbol{M n O}, \boldsymbol{\square} \mathrm{Li}_{2} \mathrm{CO}_{3}\right)$

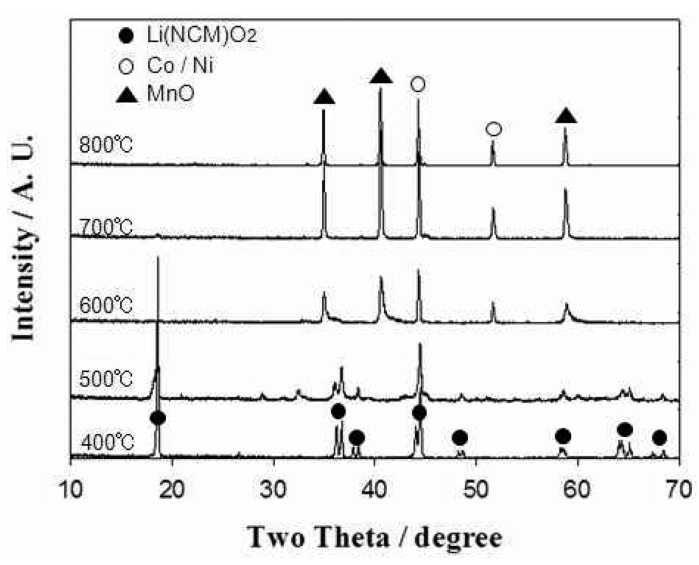

Fig. 7. XRD patterns of NCM system Li-ion battery scrap powders after washing process. $\left(-\mathrm{Li}(\mathrm{NCM}) \mathrm{O}_{2}\right.$, $\mathrm{Co} / \mathrm{Ni}, \boldsymbol{\Delta} \mathrm{MnO})$

은 약 $4.7 \%$ 였지만, $500^{\circ} \mathrm{C}$ 이상의 온도에서 환원 침출 된 분말의 경우에는 약 $9.7 \%$ 로 침출율이 증가하였으며, $600^{\circ} \mathrm{C}, 700^{\circ} \mathrm{C}, 800^{\circ} \mathrm{C}$ 에서는 $65.8 \%, 71.6 \%, 72.3 \%$ 로 급격히 증가하였다. 그 이유는 $600^{\circ} \mathrm{C}$ 부터 탄소에 의해 환원됨에 따라 리튬이 카본과 반응하여 탄산리튬을 생 성하였기 때문이라 판단된다.

그리고 리튬을 회수하기 위하여 $700^{\circ} \mathrm{C}$ 에서 탄소로 환원 처리된 분말 수세액을 증발농축기를 사용하여 농 축시켜 여과를 통하여 손쉽게 탄산리튬을 회수하였다.

제조된 탄산리튬 분말의 순도는 $\mathrm{ICP}$ 의 분석 결과 약 $99 \%$ 이상이었다. 또한, 입자에 대한 XRD 및 $\mathrm{SEM}$ 의 결과를 Fig. 9과 Fig. 10에 나타내었다. 그 결과 


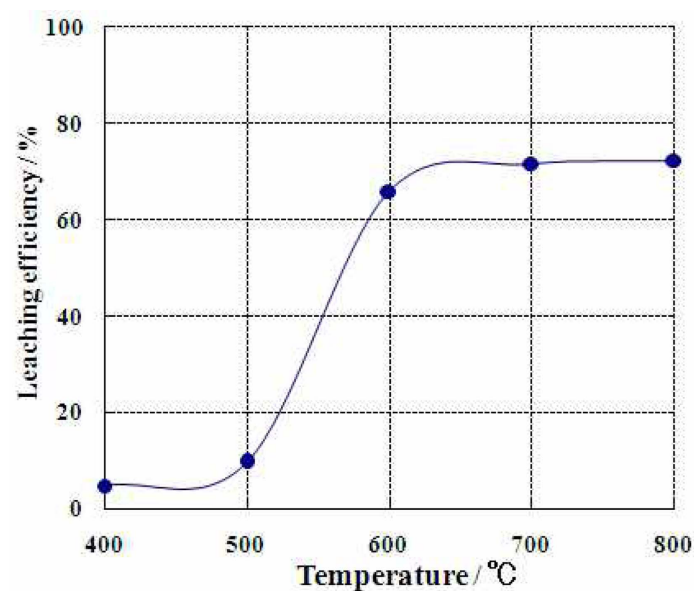

Fig. 8. Leaching efficiency of lithium after carbon reduction.

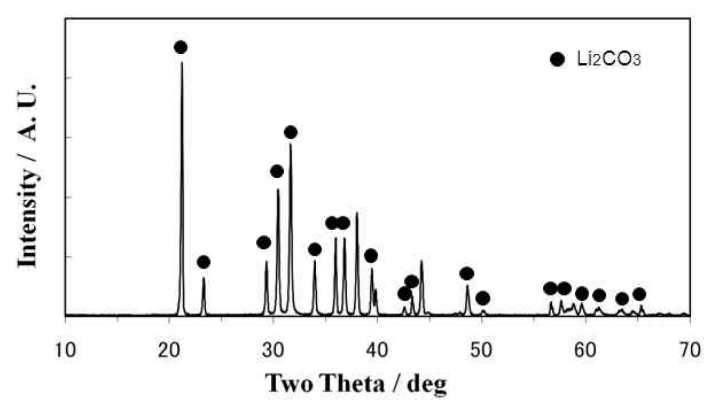

Fig. 9. The XRD patterns of $\mathrm{Li}_{2} \mathrm{CO}_{3}$.

$\mathrm{Li}_{2} \mathrm{CO}_{3}$ 이외에 약간 미지의 피크가 관측되었으며, 생성 된 결정상은 부정형의 모양으로 생성됨을 알 수 있었다.

\section{3. 산 침출 실험}

온도에 따라 탄소환원 처리된 $\mathrm{NCM}$ 계 이차전지 공정 스크랩 분말에 대한 황산에 따른 유가금속의 침출거동 을 알아보기 위한 실험을 실시하였다. XRD 분석에 의 하여 탄소환원으로 반응이 진행되어 거의 완료가 이루 어지는 온도를 $800^{\circ} \mathrm{C}$ 로 판단되어 $400^{\circ} \mathrm{C}$ 에서 $800^{\circ} \mathrm{C}$ 까지 $100^{\circ} \mathrm{C}$ 간격으로 1 시간 열처리하여 리튬을 회수하기 위하 여 수세한 분말을 $2 \mathrm{M}$ 의 황산농도로 하여 침출하였다.

고액비는 $100 \mathrm{~g} / \mathrm{L}$ 고정시켜 침출실험을 하였으며, 그 결과를 Fig. 11 에 나타내었다. $500^{\circ} \mathrm{C}$ 에서의 $2 \mathrm{M}$ 황산에 대하여서는 코발트 $88 \%$, 니켈 $85 \%$, 망간 $80 \%$ 로 침출 되었으며, $600^{\circ} \mathrm{C}$ 이상에서는 $99 \%$ 이상 침출되었다. 그 이유는 탄소환원에 의하여 $\mathrm{NCM}$ 계 분말이 탄소와 반응

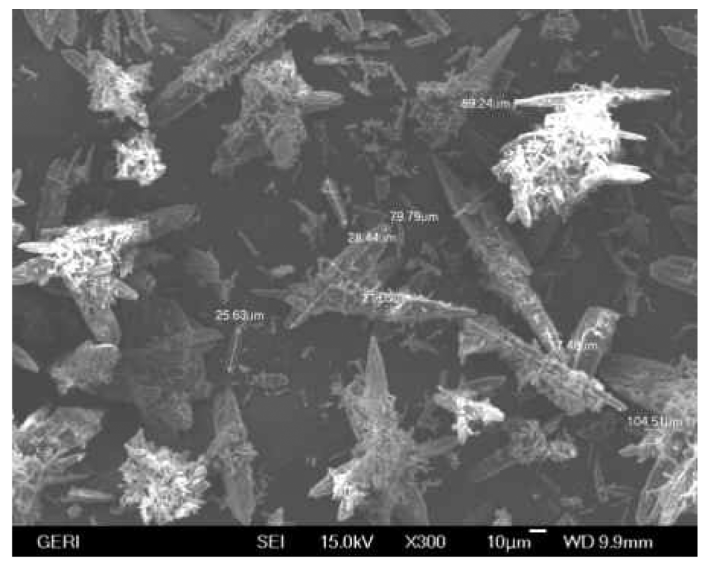

Fig. 10. The SEM photograph of $\mathrm{Li}_{2} \mathrm{CO}_{3}$.

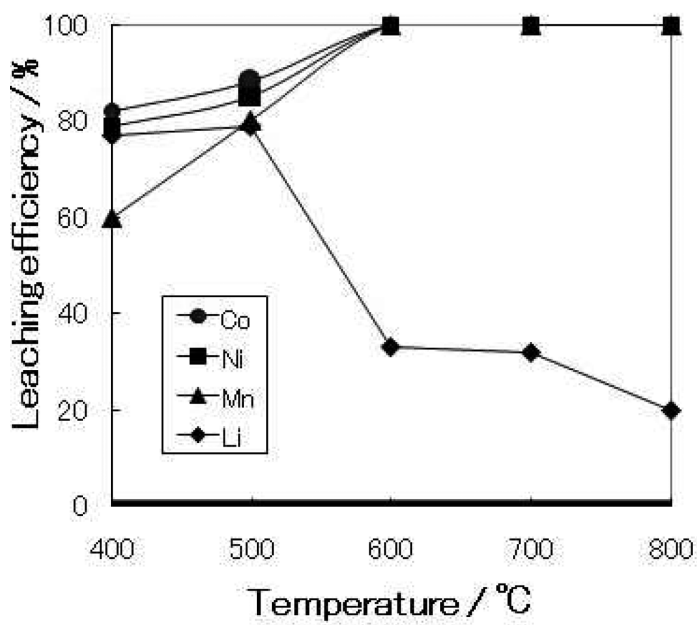

Fig. 11. The leaching efficiency of metal components according to $2 \mathrm{M}$ sulfuric acid concentration.

하여 코발트 및 니켈은 금속 상태로 존재하고 망간의 경우에는 황산에 잘 녹는 망간산화물 상태로 존재하기 때문이다. 또한 리튬의 경우에는 고액비 $100 \mathrm{~g} / 4000 \mathrm{~mL}$ 로 하여 수세하였음에도 불구하고 $600^{\circ} \mathrm{C} \sim 800^{\circ} \mathrm{C}$ 에서 수세 처리된 분말에서는 약 $30 \%$ 리튬이 존재하여 있음 을 알 수 있었다.

온도에 따른 탄소환원 결과를 볼 때 가능한 한 리튬 을 많이 회수하고 황산에 잘 침출되는 온도는 $600^{\circ} \mathrm{C}$ 이상으로 황산농도별 침출 실험에서는 $700^{\circ} \mathrm{C}$ 로 고정하 여 실험을 실시하였다. 탄소를 이용한 환원반응 전후 분 말에 대한 황산농도에 따른 침출비교에 대한 결과를 Fig. 12에 나타내었다. 전체적으로 탄소환원 처리된 분 


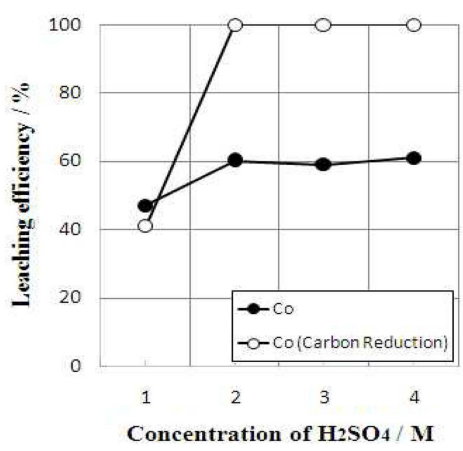

(a) $\mathrm{Co}$

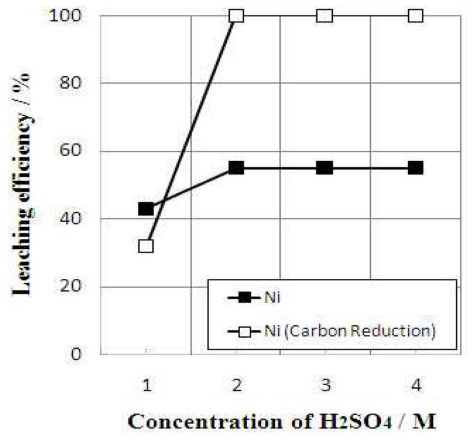

(b) $\mathrm{Ni}$

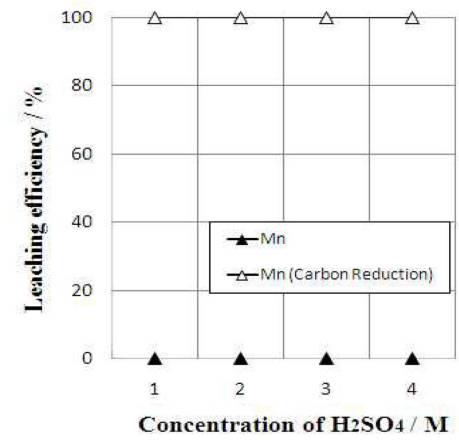

(c) $\mathrm{Mn}$

Fig. 12. The leaching efficiency of metal components according to sulfuric acid concentration ; (a) $\mathrm{Co}$, (b) $\mathrm{Ni}$, (c) $\mathrm{Mn}$

말이 동일한 조건에서 원료분말에 대한 황산 침출율보 다 월등히 높게 나타내었다. 황산 농도 $2 \mathrm{M}$ 을 기준으로 하여 비교하여 보면, 코발트의 경우에는 약 $40 \%$, 니켈 의 경우에는 약 $45 \%$, 망간의 경우에는 침출율이 매우 크게 상승하였다. 이는 탄소환원 처리에 의하여 XRD 결과에도 언급하였다시피 $\mathrm{Li}(\mathrm{M}=\mathrm{NCM}) \mathrm{O}_{2}$ 상태에서 코 발트 및 니켈은 금속상태로 환원되었으며, 망간은 $\mathrm{MnO}$ 의 형태로 존재하며, 이는 황산에 잘 녹기 때문으로 판 단된다.

\section{4. 결}

$\mathrm{NCM}$ 계 이차전지 공정 스크랩 분말에 대한 탄소환원 처리에 따른 리튬회수 및 황산 침출 거동에 대하여 다 음과 같은 결론을 얻었다.

1) 탄소를 이용한 환원반응에 따른 무게 감량은 $400^{\circ} \mathrm{C}$ 에서 약 $3 \%$ 였으며, $700^{\circ} \mathrm{C}$ 에서 약 $13 \%$ 감소하였 으며, 이때의 탄소환원에 의한 반응율은 약 $75 \%$ 였다.

2) 탄소환원 온도에 따른 결정상의 변화는 $\mathrm{XRD}$ 로 평가하였다. $400^{\circ} \mathrm{C}$ 에서는 $\mathrm{Li}(\mathrm{NCM}) \mathrm{O}_{2}$ 피크가 거의 변 하지 않았으며, $500^{\circ} \mathrm{C}$ 에서는 $\mathrm{Li}(\mathrm{NCM}) \mathrm{O}_{2}$ 피크가 변하 기 시작하여, $600^{\circ} \mathrm{C}$ 부터는 $\mathrm{Li}_{2} \mathrm{CO}_{3}, \mathrm{Co}, \mathrm{Ni}, \mathrm{MnO}$ 피 크가 존재하였다.

3) $\mathrm{NCM}$ 계 이차전지 공정 스크랩 분말에 탄소 환원 처리 후 리튬회수 결과를 보면, $400^{\circ} \mathrm{C}$ 에서 약 $5 \%$ 침 출율을 나타내었으며, 환원온도가 올라감에 따라 침출 율도 증가하여 $600^{\circ} \mathrm{C}$ 에서는 약 $66 \%$ 로 급격히 증가하 여 $800^{\circ} \mathrm{C}$ 에서는 약 $72 \%$ 를 나타내었다. $600^{\circ} \mathrm{C}$ 부터 리 툼의 침출율이 급격히 증가한 이유는 리튬이 탄소와 반 응하여 $\mathrm{Li}_{2} \mathrm{CO}_{3}$ 을 생성하였기 때문이라 판단되며, 리튬
침출액에 대한 농축에 의해 생성된 탄산리튬의 순도는 약 $99 \%$ 였다.

4) $\mathrm{NCM}$ 계 이차전지 공정 스크랩 분말에 탄소 환원 처리 전후 황산 침출 결과를 보면, 탄소환원 처리 후의 분말은 $2 \mathrm{M}$ 이상의 황산농도에서 코발트, 니켈, 망간의 침출율은 $99 \%$ 이상 침출되었으며, 환원 처리 전에 비 하여 침출효율이 코발트 약 $40 \%$, 니켈 약 $45 \%$ 향상 되었으며, 망간의 경우에는 환원 처리 전 황산에는 거 의 침출이 되지 않았지만, 환원 처리 후 산화망간으로 변 함에 따라 $99 \%$ 이상 상당한 침출됨을 알 수 있었다.

\section{사 사}

본 연구는 중소기업청에서 시행하는 2012년도 중소 기업기술개발지원사업 기술혁신개발사업에 의하여 “리 튬이온전지 스크랩을 원료로 한 $\mathrm{NCM}$ 전구체 및 고순 도 리튬화합물 제조기술개발"에 관한 일련의 연구로 수 행되었으며, 이에 감사드립니다(과제번호 S2045890).

\section{참고문헌}

1. H. C. Jung et al., 2010: Overview and future concerns for lithium-ion batteries materials, J. Korean Powder Metallurgy Institute, 17(3) pp. 175-189.

2. H. K. Park, 2008: The research and development trend of cathode materials in lithium ion battery, J. Korean Electrochem. Soc., 11(3), pp. 197-210.

3. H. S. Hong et al., 2011: Overview and Prospects for cathode materials of lithium secondary batteries, Trend in Metals \& Materials Engineering, 24(1), pp. 26-32.

4. G. C. Shim, 2011: A state of art review on lithium-ion 
batteries for vehicular applications, Trend in Metals \& Materials Engineering, 24(6), pp. 49-64.

5. P. Zhang et al., 1998: Hydrometallurgical process for recovery of metal values from spent lithium-ion secondary batteries, Hydrometallurgy, 47, pp. 259-271.

6. M. Contestabile et al., 2001: A laboratory-scale lithium-ion battery recycling process, J. of Power Sources, 92, pp. 6569.

7. C. K. Lee and N. H. Kim, 2001: Reductive leaching of $\mathrm{LiCoO}_{2}$ in a sulfuric acid solution, J. Korean Inst. of Resources Recycling, 10(6), pp. 9-14.

8. S. Castillo et al., 2002: Advances in the recovering of spent lithium battery compounds, J. of Power Sources, 112, pp. 247-254

9. J. Nan et al., 2005: Recovery of metal values from spent lithium-ion batteries with chemical deposition and solvent extraction, J. of Power Sources, 152, pp. 278-284.

10. R. Wang et al., 2009: A novel recovery process of metal values from the cathode active materials of the lithium-ion secondary batteries, Hydrometallurgy, 99, pp. 194-201.
11. C. Liang et al., 2011: Separation and recovery of $\mathrm{Ni}$, Co, Mn from spent lithium-ion batteries, The Chinese J. of Nonferrous Metals., 21(5), pp. 1192-1198.

12. S. K. Kim et al., 2011: The high efficient physical and chemical treatment of spent lithium ion battery module of electric vehicle for recovery of valuable metals, The 2011 spring meeting and $36^{\text {th }}$ conference, Korean Inst. of Resources Recycling, pp. 84-89.

13. D. W. Kim et al., 2011: Recovery of lithium and leaching behavior of NCM powder by reductive treatment from NCM-system Li-ion battery scraps, Digests of the 2012 fall meeting and $39^{\text {th }}$ conference, Korean Inst. of Resources Recycling, pp. 233-240.

14. C. K. Lee and D. H. Yang, 2001: Recovery of valuable metals from spent lithium ion batteries, J. Korean Ind. Eng. Chem., 12(8), pp. 890-895.

15. R. Kononov, 2008: Carbothermal solid state reduction of manganese oxide and ores in different gas atmospheres, $\mathrm{Ph}$. D. thesis, The University of New South Wales.

\section{金 大 原}

• 현재 (주)타운마이닝캄파니 연구소장

- 당 학회지 제 20 권 4 호 참조
張 成 太

- 현재 (주)타운마이닝캄파니 선임연구원

- 당 학회지 제 20 권 4 호 참조 